\title{
Bromate removal by electrochemical reduction at boron-doped diamond electrode
}

\author{
Xu Zhao, Huijuan Liu*, Angzhen Li, Yuanli Shen, Jiuhui Qu \\ State Key Laboratory of Environmental Aquatic Chemistry, Research Center for Eco-Environmental Sciences, Chinese Academy of Sciences, Beijing 100085, PR China
}

\section{A R T I C L E I N F O}

\section{Article history:}

Received 25 July 2011

Received in revised form

27 November 2011

Accepted 6 December 2011

Available online 16 December 2011

\section{Keywords:}

Bromate removal

Electroreduction

BDD electrode

Graphite

Carbon paper

\begin{abstract}
A B S T R A C T
The electrochemical removal of bromate ions was performed with BDD electrodes in a two-compartment electrolytic reactor. Bromate ions removal and the production of $\mathrm{Br}^{-}$were observed and determined. The removal of bromate ions occurred at an applied bias potential of $-0.45 \mathrm{~V}$ (vs. SCE). And, the removal rate increased with the applied bias potential. Within $2 \mathrm{~h}$, nearly $90 \%$ of bromate ions were removed with the applied bias potential of $-1.0 \mathrm{~V}$ (vs. SCE). Effect of $\mathrm{pH}$ on bromate ions removal was slight. $\mathrm{SO}_{4}{ }^{2-}$ and $\mathrm{Cl}^{-}$ ions inhibit the electrochemical reduction of bromate ions, which can be explained by the competitive adsorption of coexisting anions at the electrode surface with the bromate ions. In comparison, the graphite and carbon paper electrode exhibit low catalytic activities toward reduction removal of bromate ions under the same experimental conditions. A possible reason was proposed.
\end{abstract}

(c) 2012 Elsevier Ltd. All rights reserved.

\section{Introduction}

Bromide $\left(\mathrm{Br}^{-}\right)$is naturally present in most water bodies, with concentrations varying from a few micrograms per liter to several milligrams per liter. It can be oxidized to form bromate ions $\left(\mathrm{BrO}_{3}{ }^{-}\right)$ in drinking water through disinfection processes such as ozonation, hypochlorination, chloramination, or a combination of ozonation and hypochlorination [1]. Although evidence of carcinogenicity in humans is inadequate, the International Agency for Research on Cancer has classified it as a Group 2B substance. The world Health Organization recommends a provisional guideline value of $0.01 \mathrm{mg} / \mathrm{L}$ for drinking water [2].

Different approaches have been taken to reduce $\mathrm{BrO}_{3}{ }^{-}$concentrations in drinking water. The majority of studies have focused on optimizing ozonation processes to minimize bromate formation [3]. In addition, removal of $\mathrm{BrO}_{3}{ }^{-}$after its formation has also been investigated [4,5]. Various technologies for $\mathrm{BrO}_{3}{ }^{-}$removal have been discussed, such as photocatalytic reduction [6], activated carbon adsorption [7], zero iron reduction [8], and biological remediation. Bromate removal by ferrous iron and biologically activated carbon was popular. However, the issue of cost-effectively removing residual iron from the water stream must be resolved prior to development of a viable full-scale technique, because the WHO

\footnotetext{
* Corresponding author. Tel.: +86 10 62849160; fax: +86 1062849160 .

E-mail address: hjliu@rcees.ac.cn (H. Liu).
}

guidelines for drinking-water quality recommends iron concentrations less than $300 \mu \mathrm{g} / \mathrm{L}$.

Consequently, it is meaningful to provide a new option to remove $\mathrm{BrO}_{3}{ }^{-}$from the water stream. Mussini and Longhi summarized the standard potential of $\mathrm{BrO}_{3}{ }^{-}$and $\mathrm{HOBr}$ as follows [9]:

$$
\begin{array}{ll}
\mathrm{BrO}_{3}{ }^{-}+5 \mathrm{H}^{+}+4 \mathrm{e}^{-} \rightleftarrows \mathrm{HOBr}+2 \mathrm{H}_{2} \mathrm{O} & 1.447 \mathrm{VvsSHE} \\
\mathrm{HOBr}+\mathrm{H}^{+}+2 \mathrm{e}^{-} \rightleftarrows \mathrm{Br}^{-}+\mathrm{H}_{2} \mathrm{O} & 1.341 \mathrm{VvsSHE}
\end{array}
$$

These potentials clearly show $\mathrm{BrO}_{3}{ }^{-}$and $\mathrm{HOBr}$ act as oxidants and electrochemical reduction of $\mathrm{BrO}_{3}{ }^{-}$may proceed at the cathode in an electrochemical system. Several electrode materials catalyzing $\mathrm{BrO}_{3}{ }^{-}$reduction were reported such as molybdenum oxide, tungsten oxide, and polyoxometalate. These metallic oxides were applied to amperometric detection of $\mathrm{BrO}_{3}{ }^{-}$[10-12]. However, application of the metallic oxides for water treatment is limited because of their instability as a cathode. A stability of an electrode is an important factor in water treatment. Accordingly, $\mathrm{BrO}_{3}{ }^{-}$ reduction by a stable electrode is desired for water treatment.

Boron-doped diamond (BDD) films have been largely used as electrode material in electrochemical studies since BDD films posses an extraordinary chemical stability and low capacitive currents in an extended range of potential [13]. The recent use of BDD thin-film in anodic oxidation of organic pollutants has been largely investigated [14-18]. It is known that carbon materials such as vitreous carbon [19], carbon felt [20], and carbon nanotube [21] can be used as cathode materials to reduce organic contaminants or 


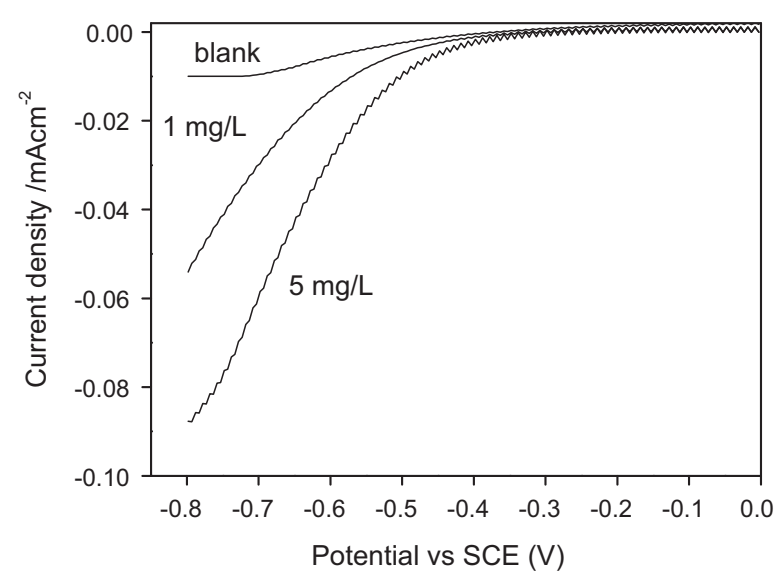

Fig. 1. Cyclic voltammograms of $\mathrm{BrO}_{3}{ }^{-}$ions with various concentrations at $\mathrm{BDD}$ electrode ( $\mathrm{pH} 7.5,0.1 \mathrm{mM} \mathrm{Na}_{2} \mathrm{SO}_{4}$ solution).

metal ions. However, there have been very few investigations of BDD electrodes employed as cathodes. Bouamrane et al. studied the effectiveness of BDD for reducing nitrate to ammonia [22]. Several studies have investigated metal deposition, including mercury, silver, copper, and cadmium [23,24]. Reduction of trichloroethene at BDD electrodes was also reported and production of acetate and chloride ions with no detectable intermediates was observed [25].

Herein, the effectiveness of a BDD cathode for reductive destruction of $\mathrm{BrO}_{3}{ }^{-}$ions was examined. Effects of $\mathrm{pH}$ and applied bias potential on the removal of $\mathrm{BrO}_{3}-$ ions were investigated. Reduction of $\mathrm{BrO}_{3}-$ ions at the graphite and carbon paper electrode was also checked.

\section{Experimental}

$\mathrm{BrO}_{3}{ }^{-}$solution with given concentration was prepared by the dilution of potassium bromate solution $\left(\mathrm{KBrO}_{3}\right.$, analytical grade) with distilled water. The solution $\mathrm{pH}$ was adjusted by addition of sulfuric acid $\left(\mathrm{H}_{2} \mathrm{SO}_{4}\right.$, guaranteed grade) and potassium hydroxide ( $\mathrm{KOH}$, guaranteed grade).

Electrochemical experiments were performed in a twocompartment electrolytic cell divided by a cation exchange membrane (Nafion N-117, DuPont, Willmington, DE). Each cell was a rectangular glass block measuring $10 \mathrm{~cm}$ in height, $5.2 \mathrm{~cm}$ in width, and $5.0 \mathrm{~cm}$ in length. Electrolyte in both compartments of the cell was mixed by a stir bar and magnetic stir plate. BDD electrode (Adamant Technologies SA, $4 \mathrm{~cm} \times 5 \mathrm{~cm}$ ) was used as the cathode; a $\mathrm{Pt}$ wire was used as the anode; the saturated $\mathrm{KCl}$ electrode was used as the reference electrode. Each cell is left unsealed and exposed to room air. The electrochemical reaction employed a basic electrochemical system (Basic electrochemical system, Princeton Applied Research Co., U.S.A).

The concentrations of bromate and bromide ions were determined by ion chromatography (Dionex, ICS-1000) with an IonPac AG15 guard column and an IonPac AS15 analytical column. All the experiments were performed at least in duplicate. The reported values are within the experimental error of $\pm 2.0 \%$.

\section{Results and discussion}

\subsection{Electrochemical behavior of $\mathrm{BrO}_{3}{ }^{-}$at $\mathrm{BDD}$ electrode}

As shown in Fig. 1, the linear sweep voltammetry of the BDD electrode in $0.1 \mathrm{mM} \mathrm{Na} 2 \mathrm{SO}_{4}$ with various $\mathrm{BrO}_{3}{ }^{-}$ion concentrations $(10 \mathrm{mV} / \mathrm{s})$ shows a cathodic current starting at $-0.45 \mathrm{~V}$ (vs.

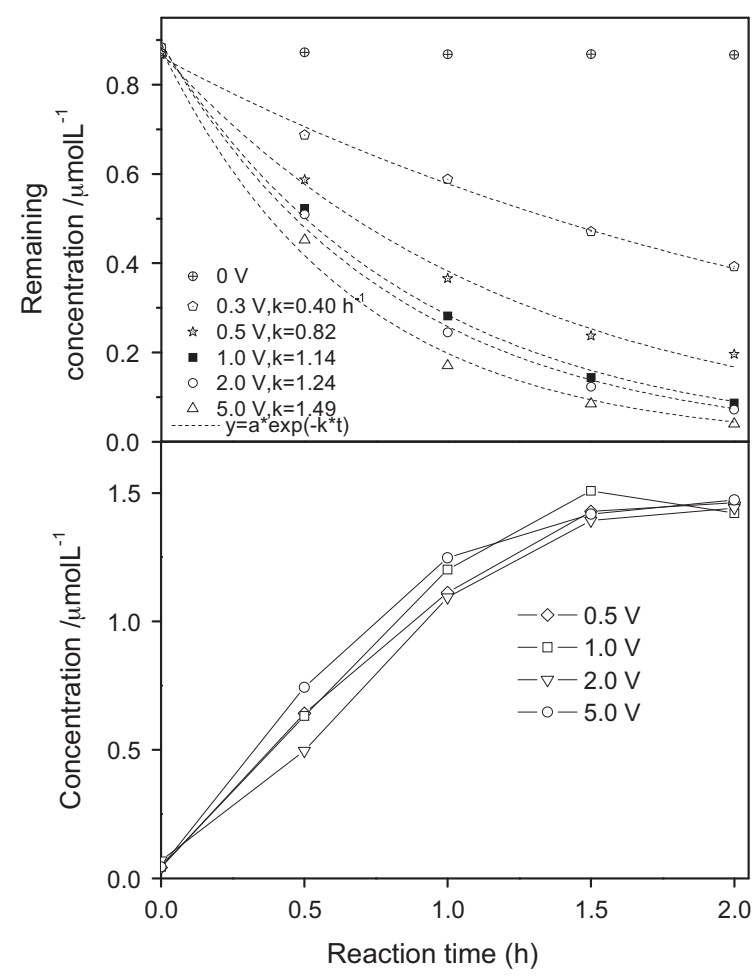

Fig. 2. Effect of applied bias potential on $\mathrm{BrO}_{3}{ }^{-}$removal and $\mathrm{Br}^{-}$formation at $\mathrm{BDD}$ electrode $\left(0.1 \mathrm{mM} \mathrm{Na}_{2} \mathrm{SO}_{4}\right.$ solution).

$\mathrm{SCE})$. The peak intensity increases with the concentration of $\mathrm{BrO}_{3}{ }^{-}$ ions, which indicates that the $\mathrm{BrO}_{3}{ }^{-}$ions can be reduced by BDD electrode.

\subsection{Effect of applied bias potential on bromate removal}

As shown in Fig. 2, no decrease in $\mathrm{BrO}_{3}{ }^{-}$ions occurred without electrolysis. Thus, the BDD electrode used in this study exerted no catalytic activity on $\mathrm{BrO}_{3}{ }^{-}$without electrochemical bias application and adsorption of $\mathrm{BrO}_{3}{ }^{-}$on the BDD electrode was negligible. By contrast, $\mathrm{BrO}_{3}{ }^{-}$removal was observed when the applied bias potential was applied. Corresponding $\mathrm{Br}^{-}$ions were also detected. The sum of molar concentration of $\mathrm{BrO}_{3}{ }^{-}$and $\mathrm{Br}^{-}$reached over $70 \%$ of the initial $\mathrm{BrO}_{3}{ }^{-}$concentration, indicating that most of the $\mathrm{BrO}_{3}{ }^{-}$ removed was electrochemically reduced to $\mathrm{Br}^{-}$. The bromous or hypobromous will be generated in the electrochemical reduction of bromate, which is unstable and the disproportionation reaction will occur as described by Lee and Lister [26].

The bromate reduction rate constants $\left(k_{1}\right)$, obtained using a first-order reaction rate to simulate the data in Fig. 2, are 0.40, $0.82,1.14,1.24$, and $1.49 \mathrm{~h}^{-1}$ for $0.3,0.5,1.0 .2 .0$ and $5.0 \mathrm{~V}$, respectively. All of the $R^{2}$ values were larger than 0.99. Such apparent bromate reduction rates provide a relative comparison of the effectiveness of bromate reduction with various applied bias potential. It is observed that removal efficiency of $\mathrm{BrO}_{3}{ }^{-}$increases with the applied bias potentials. And, the increase is slight when the applied bias potential is higher than $1.0 \mathrm{~V}$. The reduction removal of organic or inorganic compounds at cathode was mainly via direct electron reduction or indirect hydrogen atoms reduction [27]. The cathodic reduction of $\mathrm{BrO}_{3}{ }^{-}$is thermodynamically superior to hydrogen evolution. Therefore, at an applied bias potential less than $-1.0 \mathrm{~V}$, $\mathrm{BrO}_{3}-$ may be electrochemically reduced without hydrogen evolution. 


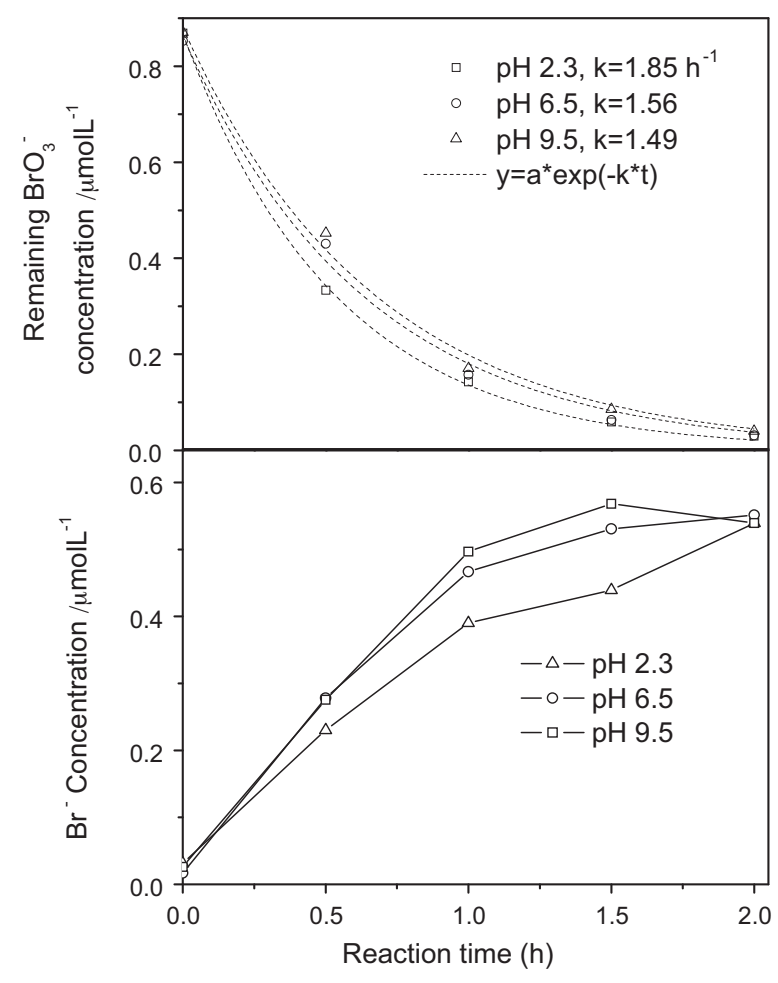

Fig. 3. Effect of $\mathrm{pH}$ values on bromate removal and $\mathrm{Br}^{-}$formation at $\mathrm{BDD}$ electrode (0.1 $\mathrm{mM} \mathrm{Na}_{2} \mathrm{SO}_{4}$ solution).

\subsection{Effect of $\mathrm{pH}$ on bromate removal}

The electroreduction process produces hydroxide ions at the surface of cathode so the $\mathrm{pH}$ near the surface is most probably higher than that in the bulk solution and the $\mathrm{pH}$ of an unbuffered electrolysis medium increases as the electrolysis proceeds. Removal of bromate ions under various $\mathrm{pH}$ conditions with a constant applied bias potential of $-2.0 \mathrm{~V}$ was investigated. As shown in Fig. 3, the removal rate of bromate ions increase slightly with the decrease of solution $\mathrm{pH}$. It has been reported that the removal of bromate ions strongly depended on solution $\mathrm{pH}$, with low $\mathrm{pH}$ accelerating the removal rate. The similar dependency on $\mathrm{pH}$ in GAC treatment was observed by Kishimoto and Matsuda [4]. Bromic acid $\left(\mathrm{HBrO}_{3}\right)$ may be more reactive than $\mathrm{BrO}_{3}{ }^{-}$because anions are generally difficult to approach the cathode because of electrostatic repulsive force [28].

The CV curve of BDD electrode with and without $\mathrm{BrO}_{3}{ }^{-}$ions under basic, neutral and acid conditions were given in Fig. 4. It can be seen that the current variation under various $\mathrm{pH}$ conditions was slight. By contrast, the obvious differences of current values were observed in the presence of $\mathrm{BrO}_{3}{ }^{-}$ions. The cathodic current at $\mathrm{pH}$ 4.2 was larger than that at $\mathrm{pH} 6.8$. And, the cathodic current was low in the $\mathrm{pH}$ of 8.5 . The above results indicated that the reduction of $\mathrm{BrO}_{3}{ }^{-}$ions was favorable in the acid conditions. Additionally, in the presence of bromate, the evolution of $\mathrm{H}_{2}$ will be inhibited and the current in the $\mathrm{CV}$ with bromate was smaller than that without bromate ions. In an alkaline medium, hydroxide ions occupy active sites and hindered the adsorption of bromate ions, which may be responsible for the enhanced reduction rate of $\mathrm{BrO}_{3}-$ ions.

\subsection{Effect of coexisting ions on bromate removal}

$\mathrm{Cl}^{-}, \mathrm{SO}_{4}{ }^{2-}, \mathrm{SiO}_{3}{ }^{2-}$, and $\mathrm{CO}_{3}{ }^{2-}$ were ubiquitous present in drinking water, which were selected to assess the impact of coexisting anions on the bromate reduction. Catalytic bromate reduction in

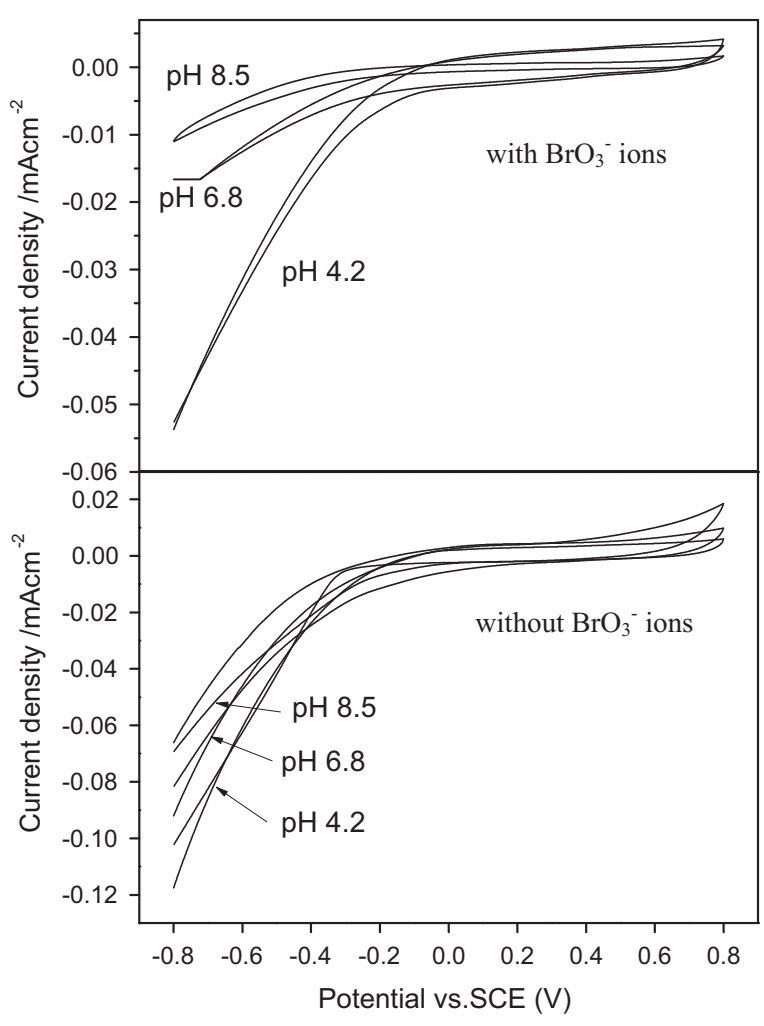

Fig. 4. Cyclic voltammograms of $\mathrm{BDD}$ electrode with and without $\mathrm{BrO}_{3}{ }^{-}$ions (0.1 $\mathrm{mM} \mathrm{Na}_{2} \mathrm{SO}_{4}$ solution, $20 \mathrm{mg} / \mathrm{L} \mathrm{BrO}_{3}{ }^{-}$ions).

the presence of $\mathrm{Cl}^{-}, \mathrm{SO}_{4}{ }^{2-}, \mathrm{SiO}_{3}{ }^{2-}$, and $\mathrm{CO}_{3}{ }^{2-}$ with various concentrations is compared. As shown in Fig. 5, a consistent trend is observed that the presence of coexisting anions led to suppress bromate reduction and the inhibition effect was promoted with the increase of anion concentration. And, $\mathrm{SO}_{4}{ }^{2-}$ exhibits the most prominent inhibition effect on the bromate reduction among all anions tested. The reduction of bromate at very negative potentials $(-2.0 \mathrm{~V}$ vs. SCE) takes place far from the electrode surface, possibly at the outer Helmholtz plane (oHp), because they are repelled from the likely charged electrode. Therefore, the direct adsorption of bromate on the electrode surface under these conditions is not possible. The inhibition may be related with the ability of bromate to approach the $\mathrm{oHp}[29]$. The adsorption affinity to anion-exchange resins is ordered as follows: $\mathrm{SO}_{4}{ }^{2-}>\mathrm{Cl}^{-}>\mathrm{SiO}_{3}{ }^{2-} \approx \mathrm{CO}_{3}{ }^{2-}[30]$. The

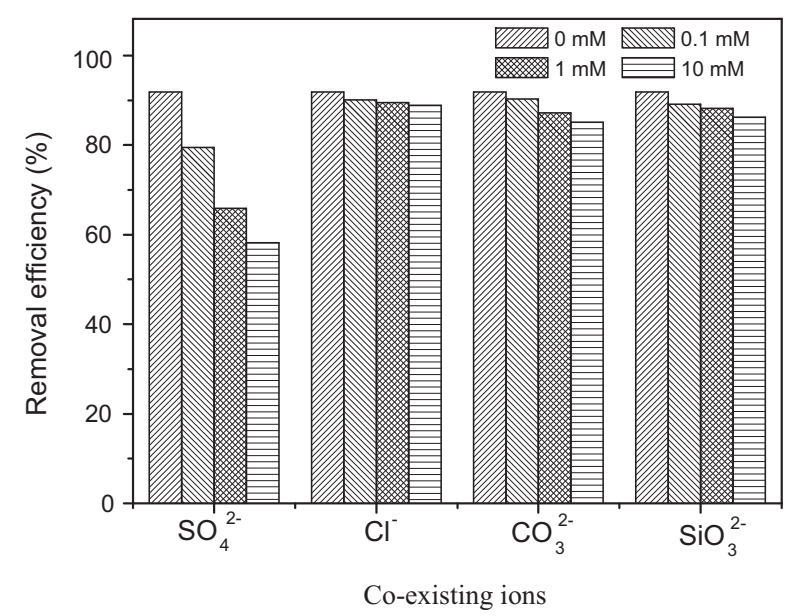

Fig. 5. Effects of co-existing ions on the removal of bromate ions with the applied bias potential of $-2.0 \mathrm{~V}$ and reaction time of $2 \mathrm{~h}$. 


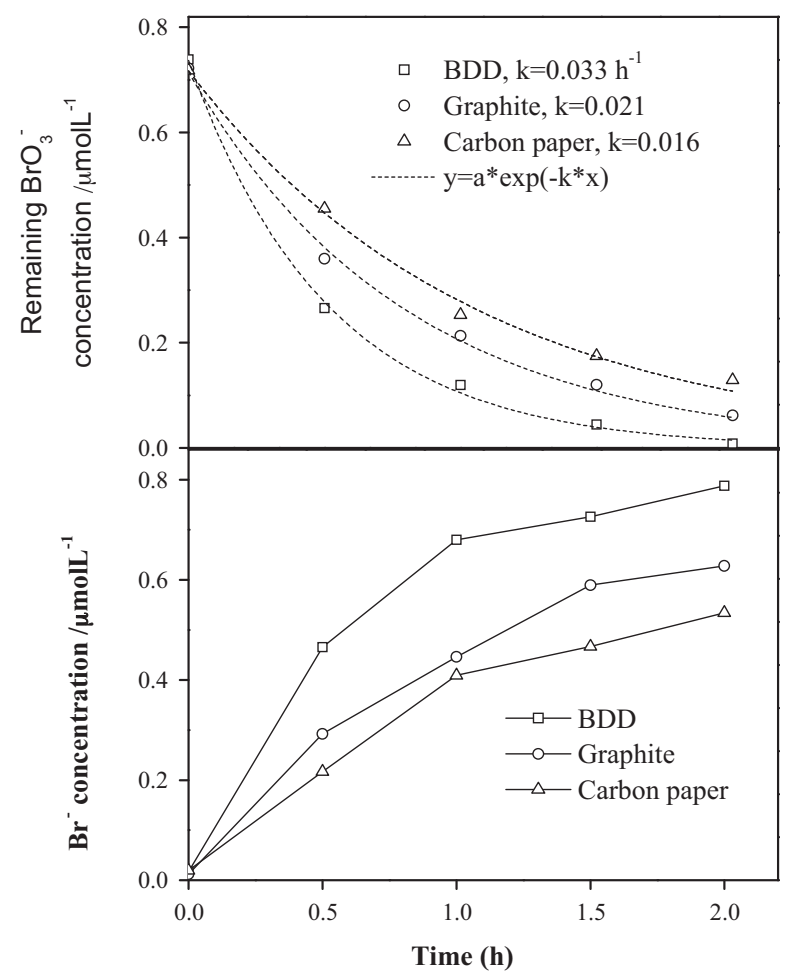

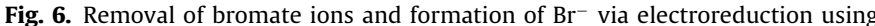
various electrode materials with same experiment conditions ( $\mathrm{pH}$ 6.5, applied bias potential $-1.0 \mathrm{~V})$.

observed sequence of inhibition effects of the tested anions on the bromate reduction was consistent with the above sequence. In general, an anion with high ionic charge and small ionic size invokes strong electrostatic interaction. Compared to $\mathrm{Cl}^{-}, \mathrm{SO}_{4}{ }^{2-}$ has higher ionic charge, resulting in stronger inhibition effect on the bromate reduction [31].

\subsection{Comparison with other systems}

BDD electrode, blank carbon paper electrode, and graphite electrodes are both composed of carbon atoms, terminated with oxygen or hydrogen atoms. Reduction of bromate ions at the above three kinds of electrodes with the same reaction area were investigated under same experimental conditions. It can be seen from Fig. 6 that the removal rates of bromate ions were $0.033,0.021$, and $0.016 \mathrm{~h}^{-1}$ for the BDD electrode, the carbon paper electrode, and the graphite electrode, respectively.

One possible reason for the difference in the electroreduction of bromate ions is that BDD surfaces are composed of $\mathrm{sp}^{3}$ hybridized $\mathrm{C}$ atoms bound to either two or three other $\mathrm{C}$ atoms, whereas carbon paper and graphite surfaces contain $\mathrm{sp}^{2}$-hybridized $\mathrm{C}$ atoms, bound to either one or two other $\mathrm{C}$ atoms. The specific functional groups on BDD electrodes play an important role in mediating reduction of inorganic compounds [32]. In addition, the oxygenated groups such as carboxyl, carbonyl, and hydroxyl groups at BDD electrodes are suspected to be involved in mediating electron transfer at BDD electrodes and remain on the surface even after cathodic polarization [33].

\section{Conclusions}

The obtained results indicated that bromate ions can be efficiently removed via electroreduction using BDD electrode. And, most of bromate ions were converted into bromide ions. The removal rate of bromate ions increased with the applied bias potential. The removal rate increases slightly with the solution acid degree. $\mathrm{SO}_{4}{ }^{2-}$ and $\mathrm{Cl}^{-}$ions inhibit the electrochemical reduction of bromate ions, which can be explained by the competitive adsorption of coexisting anions with the bromate ions. And, the BDD electrode exhibit higher electrocatalytic activities in bromate ions reduction than graphite and carbon paper electrodes.

\section{Acknowledgements}

This work was supported by National Natural Science Foundation of China (No. 20977103; 50621804).

\section{References}

[1] U. von Gunten, Ozonation of drinking water: part II, Water Res. 37 (2003) 1469.

[2] R. Butler, A. Godley, L. Lytton, E. Cartmell, Crit. Rev. Environ. Sci. Technol. 35 (2005) 193.

[3] R. Hofmann, R.C. Andrews, Water Res. 35 (2001) 599.

[4] N. Kishimoto, N. Matsuda, Environ. Sci. Technol. 43 (2009) 2054.

[5] W.A.M. Hijnen, R. Jong, D. Van der Kooij, Water Res. 33 (1999) 1049

[6] A. Mills, A. Belghazi, D. Rodman, Water Res. 30 (1996) 1973.

[7] M.J. Kiristis, V.L. Snoeyink, J.C. Kruithof, Water Res. 34 (2000) 4250

[8] L. Xie, C. Shang, Chemosphere 64 (2006) 919.

[9] T. Mussini, P. Longhi, Bard, A.J., Parsons, R, Jordan, J., Eds. Standard Potentials in Aqueous Solution, Marcel Dehher: New York, 1985.

[10] B. Wang, S. Dong, J. Electroanal. Chem. 379 (1994) 207.

[11] I.G. Casella, M. Contursi, Electrochim. Acta 50 (2005) 4146.

[12] A. Salimi, H. Mamkhezri, S. Mohebbi, Electrochem. Commun. 8 (2006) 688.

[13] B. Boye, E. Brillas, B. Marselli, P.A. Michaud, C. Comninellis, G. Farnia, G. Sandona, Electrochim. Acta 51 (2006) 2872.

[14] F.Montilla, P.A. Michaud, E. Morallon, J.L. Vazquez, C. Comninellis, Electrochim. Acta 47 (2002) 3509.

[15] X.M. Chen, G.H. Chen, F.R. Gao, P.L. Yue, Environ. Sci. Technol. 37 (2003) 5021

[16] J.K. Wang, J. Farrell, Environ. Sci. Technol. 38 (2004) 5232

[17] B. Nasr, G. Abdellatif, P. Canizares, C. Saez, J. Lobato, M.A. Rodrigo, Environ. Sci. Technol. 39 (2005) 7234

[18] B.P. Chaplin, G. Schrader, J. Farrell, Environ. Sci. Technol. 44 (2010) 4264.

[19] F. Rodriguez-Valadez, C. Ortiz-Exiga, J.G. Ibanez, A. Alatorre-Ordaz, S. GutierrezGranados, Environ. Sci. Technol. 39 (2005) 1875.

[20] A.I. Tsyganok, K. Otsuka, Appl. Catal. B: Environ. 22 (1999) 15.

[21] C.Y. Cui, X. Quan, H.T. Yu, Y.H. Han, Appl. Catal. B: Environ. 80 (2008) 122.

[22] F. Bouamrane, A. Tadjeddine, J.E. Butler, R. Tenne, C. Levy-Clement, J. Electroanal. Chem. 405 (1996) 95.

[23] F. Bouamrane, A. Tadjeddine, R. Tenne, J.E. Butler, R. Kalish, C. Levy-Clement, J. Phys. Chem. B 102 (1998) 134.

[24] N. Vinokur, B. Miller, Y. Avyigal, R. Kalish, J. Electrochem. Soc. 1 (1999) 125.

[25] D. Mishra, H.L. Zhao, J. Farrell. Environ. Sci. Technol. 42 (2008) 9344.

[26] C.L. Lee, M.W. Lister, Can. J. Chem. 49 (1971) 2822.

[27] B. Yang, G. Yu, J. Huang. Environ. Sci. Technol. 41 (2007) 7503.

[28] B.B. Damaskin, N.V. Fedorovich, F.S. Sarbash, J. Electroanal. Chem. 135 (1982) 181.

[29] E. Kirowa-Eisner, M.Schwarz, M. Rosenblum, E. Gileadi, J. Electrochem. Soc. 141 (1994) 1183.

[30] W.J. Weber Jr., Physicochemical Processes for Water Quality Control, WileyInterscience, New York, 1972.

[31] A.G. Volkov, S. Paula, D.W. Deamer, Bioelectrochem. Bioenerg. 42 (1997) 153.

[32] I. Duo, A. Fujishima, Ch Comninellis, Electrochem. Commun. 5 (2003) 695.

[33] H. Notsu, I. Yagi, T. Tatsuma, D.A. Tryk, A. Fujishima, Electrochem. Solid-state Lett. 2 (1999) 524. 